\title{
Seasonal and interannual variability in sources of nitrogen supporting export in the oligotrophic subtropical North Pacific Ocean
}

\author{
John E. Dore, Jennifer R. Brum, Luis M. Tupas, and David M. Karl \\ Department of Oceanography, School of Ocean and Earth Science and Technology, University of Hawaii, \\ Honolulu, Hawaii 96822
}

\begin{abstract}
Over timescales of months to years, the export of organic nitrogen from the oceanic euphotic zone (principally as sinking particulate nitrogen, PN) is believed to balance the input of exogenous combined inorganic nitrogen (i.e., export production balances new production). In the oligotrophic North Pacific subtropical gyre, there are two significant sources of new nitrogen: the upward flux of nitrate from deep water and the biological fixation of dissolved $\mathrm{N}_{2}$ in near-surface waters. Because these sources have distinct stable isotopic signatures, we were able to use the total PN and $\delta^{15} \mathrm{~N}$ measurements of sinking particles and an isotopic mass balance model to deconvolute the relative and absolute contributions of the nitrate flux and nitrogen fixation to the gravitational export of PN. The sinking flux of PN and its isotopic composition both varied widely between 1989 and 2001. Seasonally, N $_{2}$ fixation correlated inversely with mixed-layer depth, reaching a maximum in June-August, whereas nitrate-supported export correlated inversely with sea surface temperature, reaching a maximum in February-March. These patterns were consistent with summertime increases in diazotroph biomass and water column $\mathrm{N}_{2}$ fixation rates, as indicated by phycoerythrin pigment concentrations and ${ }^{15} \mathrm{~N}_{2}$ tracer studies. Annually, the relative contribution of $\mathrm{N}_{2}$ fixation to $\mathrm{N}$ export varied from 36 to $69 \%$ (mean $=48 \%$ ) and showed a significant increasing trend over the period of observation. Although total PN export correlated with the Southern Oscillation Index, the nitrate- and nitrogen fixation-based components appeared to respond to climate forcing in distinct ways, complicating our interpretation of the mechanisms of climate-induced changes in particle export.
\end{abstract}

Nitrogen is a major bioelement, and its availability often exerts a critical control on ecosystem processes, including primary photosynthetic production of organic matter. In many oceanic ecosystems, the supply of combined nitrogenous nutrients to the productive surface waters is considered a limiting resource. In the oligotrophic central gyres in particular, the rate at which exogenous or "new" nitrogen enters the euphotic zone is thought to determine the rate at which organic matter can be exported from the surface ocean (Dugdale and Goering 1967; Eppley and Peterson 1979). The primary mechanism by which organic matter is exported is the gravitational sinking of particles into the unlit deep sea and the sediments below (Knauer et al. 1990; Karl et al. 1996). Oceanographers have traditionally viewed the upward eddy-diffusive flux of nitrate $\left(\mathrm{NO}_{3}^{-}\right)$as the nearly exclusive source of new nitrogen supporting the export flux of biogenic particles in the open oceans. However, the ubiquitous pool of dinitrogen gas $\left(\mathrm{N}_{2}\right)$ dissolved in the sea can represent a significant source of new $\mathrm{N}$ when made biologically available through the activities of diazotrophic (nitrogen-fixing) microorganisms (Dugdale et al. 1961; Carpenter and Romans 1991). Recently, estimates of biological nitrogen fix-

\footnotetext{
Acknowledgments

We thank the HOT program scientists and staff, the SOEST Marine Center personnel and Seagoing Technical Assistance Group, and the captains and crews of the many research vessels that have supported this work. We also thank R. Bidigare, B. Popp, and T. Rust for analytical advice and assistance and J. Montoya for helpful comments. This work was supported by National Science Foundation grants OCE 88-00329, OCE 93-01368, and OCE 96-17409 to D.M.K., and OCE 87-17195, OCE 93-03094, and OCE 98-11921 to R. Lukas. This is SOEST contribution 5990 and U.S.-JGOFS contribution 803 .
}

ation by such diazotrophs in the tropical and subtropical oceans have been revised upward (Galloway et al. 1995; Capone and Carpenter 1999). In the North Pacific subtropical gyre (NPSG), biological $\mathrm{N}_{2}$ fixation is now thought to contribute significantly to new production and to respond in intensity to physical forcing by climatic phenomena such as El Niño (Karl et al. 1995, 1997; Deutsch et al. 2001).

Marine $\mathrm{N}_{2}$ fixation can be carried out by a number of different types of prokaryotic organisms, utilizing the enzyme nitrogenase to cleave the strong $\mathrm{N} \equiv \mathrm{N}$ triple bond to form bioavailable ammonium $\left(\mathrm{NH}_{4}^{+}\right)$. This energy-demanding process can be fueled heterotrophically or autotrophically, but in the ocean, $\mathrm{N}_{2}$ fixation appears to be carried out mostly photoautotrophically by cyanobacteria in the sunlit surface waters (Paerl 1990; Karl et al. 2002). Marine cyanobacterial diazotrophs include the large filamentous Trichodesmium, the diatom endosymbiont Richelia, and small unicellular forms (e.g., Synecchocystis, Cyanothece). All of these organisms contain the orange photosynthetic accessory pigment phycoerythrin. The large size classes (Trichodesmium and diatoms containing endosymbiotic Richelia) are thought to be responsible for the vast majority of marine $\mathrm{N}_{2}$ fixation, whereas the smaller unicells are only beginning to receive attention as potential contributors to new production (Zehr et al. 2001; Karl et al. 2002).

Stable isotopes are a useful tool for tracing bioprocesses in aquatic ecosystems. The abundance of the rare stable isotope of nitrogen $\left({ }^{15} \mathrm{~N} \sim 0.36 \%\right)$ with respect to the common stable isotope $\left({ }^{14} \mathrm{~N} \sim 99.64 \%\right)$ has therefore been widely employed in studies of the $\mathrm{N}$ cycle in the oceans (Wada and Hattori 1991). A ${ }^{15} \mathrm{~N}$-labeled tracer can be used to assess the rates of $\mathrm{N}$ cycle processes in bottle incubations (e.g., to measure the rate of $\mathrm{N}_{2}$ fixation); ${ }^{15} \mathrm{~N}_{2}$ gas can be introduced to a 
water sample and its incorporation into the particulate nitrogen (PN) pool monitored over time (Montoya et al. 1996). Differences in the natural abundance ${ }^{15} \mathrm{~N}:{ }^{14} \mathrm{~N}$ ratio among organic matter pools can also be used to constrain the source materials from which they were derived. The natural ${ }^{15} \mathrm{~N}$ : ${ }^{14} \mathrm{~N}$ ratio of recently fixed nitrogen, for example, is distinct from and lower than that of the deep pool of nitrate; thus, the relative contributions of these two sources to organic matter production can be estimated from isotope mass balances (Wada and Hattori 1991). A low ${ }^{15} \mathrm{~N}:{ }^{14} \mathrm{~N}$ ratio of PN suggests a greater role of $\mathrm{N}_{2}$ fixation in supporting its production, whereas a higher ratio indicates a greater role for $\mathrm{NO}_{3}^{-}$. Subtropical oceans typically have low ${ }^{15} \mathrm{~N}:{ }^{14} \mathrm{~N}$ in suspended particulate matter, which has been interpreted as a signature of enhanced $\mathrm{N}_{2}$ fixation (Minagawa and Wada 1986; Saino and Hattori 1987). However, recycling pathways involving the excretion of $\mathrm{NH}_{4}^{+}$by zooplankton can also "lighten" the isotopic composition of the suspended PN pool, confounding such a straightforward interpretation (Checkley and Miller 1989). The rain of sinking PN, on the other hand, to the extent that it truly represents the total export of organic nitrogen from the euphotic zone, is considered to be in balance with new nitrogen production. If $\mathrm{N}_{2}$ fixation and the upward diffusion of $\mathrm{NO}_{3}^{-}$are effectively the only sources of new $\mathrm{N}$, then the ${ }^{15} \mathrm{~N}:{ }^{14} \mathrm{~N}$ ratio of sinking PN can be used to separate these sources, free from the effects of $\mathrm{N}$ recycling within the euphotic zone (Wada and Hattori 1991; Karl et al. 1997).

In this study, we assessed the seasonal and interannual variability of $\mathrm{N}_{2}$ fixation at Station ALOHA in the NPSG using three distinct stable $\mathrm{N}$ isotopic approaches. From 1989-2001, sinking PN collected with free-floating sediment traps was analyzed for its ${ }^{15} \mathrm{~N}:{ }^{14} \mathrm{~N}$ ratio, and an isotopic mass balance was used to determine the relative contributions of $\mathrm{N}_{2}$ and $\mathrm{NO}_{3}^{-}$to export over these 12 annual cycles. Narrowing in on a single annual cycle, we measured the ${ }^{15} \mathrm{~N}:{ }^{14} \mathrm{~N}$ ratio of suspended PN from May 2000 to July 2001 in order to observe variations in the water column through the euphotic zone. On selected cruises during this period, we also conducted $\mathrm{N}_{2}$ fixation rate assays using a ${ }^{15} \mathrm{~N}_{2}$ tracer technique. Combining these approaches with diazotroph biomass estimates based on phycoerythrin measurements allowed for a detailed characterization of a single annual cycle, which we describe in the context of the long-term sediment trap record. Finally, we compare the PN isotope export record with the Southern Oscillation Index (SOI) in order to expose a possible connection between tropical climate and subtropical new and export production.

\section{Materials and methods}

Station location and sampling protocols-All sampling was carried out during the regular research cruises of the Hawaii Ocean Time-series (HOT) program to the deep-water Station ALOHA (A Long-term Oligotrophic Habitat Assessment; Karl and Lukas 1996). Station ALOHA, located at $22^{\circ} 45^{\prime} \mathrm{N}, 158^{\circ} \mathrm{W}$, is an oligotrophic open ocean site considered representative of the NPSG. The HOT program has monitored a suite of relevant physical and biogeochemical parameters at this location on a nearly monthly basis since October 1988; these core data are made available via the internet (http://hahana.soest.hawaii.edu/hot/hot_jgofs.html). Hydrographic data and water column samples were collected using an aluminum-frame CTD (conductivity, temperature, depth)/rosette sampler outfitted with 24, 12-liter PVC water bottles. Sinking particles were collected at $150 \mathrm{~m}$ using a free-floating sediment trap array designed to hold 12 replicate cylindrical traps (Karl et al. 1996).

Natural abundance of particulate ${ }^{15} \mathrm{~N}$ measurementsWater column samples were drawn from each water bottle through a $202-\mu \mathrm{m}$ Nitex mesh to exclude large zooplankton (Hebel and Karl 2001) into 4- or 10-liter polyethylene bottles. The contents were immediately pressure filtered onto precombusted Whatman GF/F filters, placed on combusted foil pieces in polystyrene Petri dishes, and frozen for transport to the shore-based laboratory. Sediment traps were processed similarly by filtering the entire contents of each trap through a combusted GF/F filter after prescreening each trap collection with a 333- $\mu$ m Nitex mesh to remove zooplankton "swimmers." After dessication at $60^{\circ} \mathrm{C}$, each filter and its associated foil piece were rolled together into a pellet for analysis of the total PN, the stable nitrogen isotopic composition of the particulates $\left(\delta^{15} \mathrm{~N}-\mathrm{PN}\right)$, or both.

For the sediment trap samples from HOT-1 (Oct 88) through HOT-112 (Feb 00), bulk particulate nitrogen analyses were carried out on replicate (usually three to six) trap collections using a commercial gas chromatographic CHN analyzer (Hewlett-Packard or Europa Scientific). Water column particulate samples (usually individual but with two or three depths typically duplicated per cruise) were similarly analyzed by CHN up through HOT-114 (Apr 00). Stable isotopic analyses of filters were carried out using either a Finnigan MAT-252 or a Finnigan Delta-S isotope ratio-monitoring mass spectrometer. From HOT-8 (Jul 89) through HOT-69 (Jan 96), a single filtered PN trap collection per cruise was converted to $\mathrm{N}_{2}$ by sealed-tube Dumas combustion/reduction with $\mathrm{Cu}$ and $\mathrm{CuO}$ followed by off-line vacuum cryodistillation, then introduced into the MAT-252 mass spectrometer along with a $\mathrm{N}_{2}$ standard gas using a dual inlet system. Beginning with HOT-113 (Mar 00) for trap samples and with HOT-115 (May 00) for water column samples, PN and $\delta^{15} \mathrm{~N}$-PN were simultaneously determined using a ConFlo-II EA/MS system for on-line introduction of the sample stream from a Carlo-Erba CHN analyzer directly into the ion source of the Delta-S mass spectrometer. Additional archived sediment trap samples from HOT-47 (May 93) through HOT-112 (Feb 00) were also analyzed using the online EA/MS method in order to fill in the gap in the timeseries record and to provide some overlap between methods. Nitrogen gas standards were independently calibrated with NIST-traceable isotopic standards. An acetanilide standard was used for calibration of PN measurements and for tracking the consistency of the CHN combustion/reduction system. In addition, an in-house reference material (ground, dried netplankton) and two NIST-certified inorganic ${ }^{15} \mathrm{~N}$ reference materials (IAEA-N1 and IAEA-N3) were used to assure the accuracy of the nitrogen isotopic measurements. All 
nitrogen isotopic measurements are reported in standard delta notation.

$$
\delta^{15} \mathrm{~N}_{\text {sample }}=\left\{\left[\frac{\left({ }^{15} \mathrm{~N} /{ }^{14} \mathrm{~N}\right)_{\text {sample }}}{\left({ }^{15} \mathrm{~N} /{ }^{14} \mathrm{~N}\right)_{\text {standard }}}\right]-1\right\} \times 1,000
$$

The reference standard is atmospheric $\mathrm{N}_{2}$ gas $\left({ }^{15} \mathrm{~N} /{ }^{14} \mathrm{~N}=\right.$ $0.0036765, \delta^{15} \mathrm{~N} \equiv 0 \%$ ) .

In all, the sediment trap data set that is utilized here consists of at least one $\delta^{15} \mathrm{~N}-\mathrm{PN}$ measurement from 104 HOT cruises out of the 128 completed through July 2001, with replicate (two or three) trap analyses from 20 of these cruises. These data span a 12 -yr period. The water column $\delta^{15} \mathrm{~N}-$ PN data include vertical profiles from all 14 HOT cruises carried out between May 2000 and July 2001, spanning a little over one annual cycle.

Nitrogen fixation assays $-{ }^{15} \mathrm{~N}_{2}$ tracer assays were conducted to assess water column $\mathrm{N}_{2}$ fixation rates during four cruises spaced throughout the annual cycle during which $\delta^{15} \mathrm{~N}-\mathrm{PN}$ measurements were conducted (HOT-117, Jul 00; HOT-120, Nov 00; HOT-124, Mar 01; HOT-127, Jun 01). These assays generally followed the method of Montoya et al. (1996) with some modifications. Water samples ( 4 liters) were drawn during early evening under subdued light, without screening, into acid-washed 4.7-liter Teflon gas sampling bags. The bags were manipulated so as to remove trapped air bubbles and stoppered with Teflon-backed septum fittings. Exactly $1 \mathrm{ml}$ of ${ }^{15} \mathrm{~N}_{2}$ gas (99\%; Isotech) at atmospheric pressure was injected through the septum with a gastight syringe and stainless steel needle. Each bag was massaged to evenly disperse and dissolve the added gas and then transferred to an appropriate temperature-controlled ondeck incubation chamber. Three chambers, shaded with blue filters to light levels of 46,6 , and $1 \%$ of incident irradiance, were used. Each sample was placed into the chamber with the light level nearest to that of the depth of collection. Incubation chamber temperatures were adjusted to be within about $\pm 1^{\circ} \mathrm{C}$ of in situ temperature.

The bags were removed from the incubators the following evening after approximately $24 \mathrm{~h}$ and were kept cool and dark during the sample processing period. Incubated samples were siphoned 1 liter at a time into graduated cylinders, the volumes recorded, and the contents transferred to 4-liter polyethylene bottles. All but a few drops of the sample were removed from each bag in this way; thus, measured incubation volumes should be accurate to within $<0.5 \%$. Measured sample volumes were then pressure-filtered through combusted GF/F filters, which were subsequently stored frozen. Selected samples were divided into two separate volumes after incubation, one of which was processed whole as described above. The other fraction was passed through a $10-\mu \mathrm{m}$ Nitex mesh prior to filtration onto a combusted GF/ $\mathrm{F}$ in order to assess the ${ }^{15} \mathrm{~N}_{2}$ fixation by the $<10-\mu \mathrm{m}$ size fraction of the plankton.

Filtered samples were dessicated, pelleted, and then analyzed for nitrogen isotopic composition on the EA/MS system as described above for $\delta^{15} \mathrm{~N}-\mathrm{PN}$. Nitrogen fixation rates were calculated from the PN and $\delta^{15} \mathrm{~N}-\mathrm{PN}$ of incubated samples, the $\delta^{15} \mathrm{~N}-\mathrm{PN}$ of parallel unincubated PN samples, the atom percent enrichment of ${ }^{15} \mathrm{~N}_{2}$ in the incubation bag (assuming $100 \%$ saturation of $\mathrm{N}_{2}$ at in situ temperature and salinity), and the duration of the incubation (Montoya et al. 1996).

Phycoerythrin measurements-The abundance of the water-soluble photosynthetic accessory pigment phycoerythrin was estimated on the $>10-\mu \mathrm{m}$ particulate size fraction of bottle-collected water samples following the in vivo glycerol-uncoupling method of Wyman (1992) as modified by R. R. Bidigare (pers. comm.). Samples (10 liters) were transferred directly from the water bottles into polyethylene transfer bottles, and these collections were then pressure-filtered through 10- $\mu \mathrm{m}$ Nitex mesh to collect large phytoplankton. These screens were placed in $20-\mathrm{ml}$ glass scintillation vials containing $5 \mathrm{ml}$ of a saline $50 \%$ glycerol solution $\left(35 \mathrm{~g} \mathrm{~L}^{-1}\right.$ $\mathrm{NaCl}$ ). The screens were placed up against the inner wall of each vial so that particles from the screens could become suspended in the solution during gentle mixing on an orbital shaker table. The phycoerythrin fluorescence (ex $=544 \mathrm{~nm}$, $\mathrm{em}=577 \mathrm{~nm}$ ) of the suspended particles was measured using a Turner Designs TD700 fluorometer, which was calibrated using buffered solutions of a commercial $R$-phycoerythrin standard (Cyanotech Corp.). The concentration of the primary standard was verified before each analytical run by measuring its absorbance $(546 \mathrm{~nm})$ spectrophotometrically. Because the in vivo fluorescence measurements were not directly compared with measurements of phycoerythrin extracted from the natural cyanobacterial populations, the absolute concentration values derived should be considered only as estimates of the true in situ pigment concentrations.

\section{Results}

PN export flux and isotopic composition-The flux of sinking particulate nitrogen at $150 \mathrm{~m}$ at Station ALOHA displayed a high degree of variability on a variety of timescales (Fig. 1A). PN flux $\left(\mathrm{F}_{\mathrm{PN}}\right)$ varied by a factor of six over the 12-yr period spanned by these observations, from a high of $593 \mu \mathrm{mol} \mathrm{m}{ }^{-2} \mathrm{~d}^{-1}$ during HOT-20 (Sep 90) to a low of $99 \mu \mathrm{mol} \mathrm{m} \mathrm{m}^{-2} \mathrm{~d}^{-1}$ during HOT-69 (Jan 96). Large flux "events" were often followed immediately by periods of low flux, producing a jagged appearance in the flux record. In addition to these large month-to-month variations in $\mathrm{F}_{\mathrm{PN}}$, low-frequency changes in the export of PN were also evident. For example, the periods from 1989 to 1991 and 1997 to 2001 exhibited high overall $\mathrm{F}_{\mathrm{PN}}$, whereas the 1992-1996 period was one of overall low $\mathrm{F}_{\mathrm{PN}}$.

The nitrogen-stable isotopic composition of the exported material $\left(\delta^{15} \mathrm{~N}-\mathrm{F}_{\mathrm{PN}}\right)$ also varied greatly, from a maximum of $6.89 \%$ during HOT-10 (Sep 89) to a minimum of $-1.17 \%$ o during HOT-102 (Feb 99). These extrema approximate the $\delta^{15} \mathrm{~N}$ values for the two significant sources of new nitrogen to this system (nitrate and dinitrogen, respectively; Fig. 1B). Both positive and negative excursions of $\delta^{15} \mathrm{~N}-\mathrm{F}_{\mathrm{PN}}$ from the mean condition occurred fairly frequently; sometimes these excursions were rapid and other times more gradual. Large spikes in the PN flux record sometimes had enriched nitrogen isotopic signatures (e.g., $\delta^{15} \mathrm{~N}-\mathrm{F}_{\mathrm{PN}}=5.61 \%$ during HOT-14, Feb 90); however, a majority of these flux events 

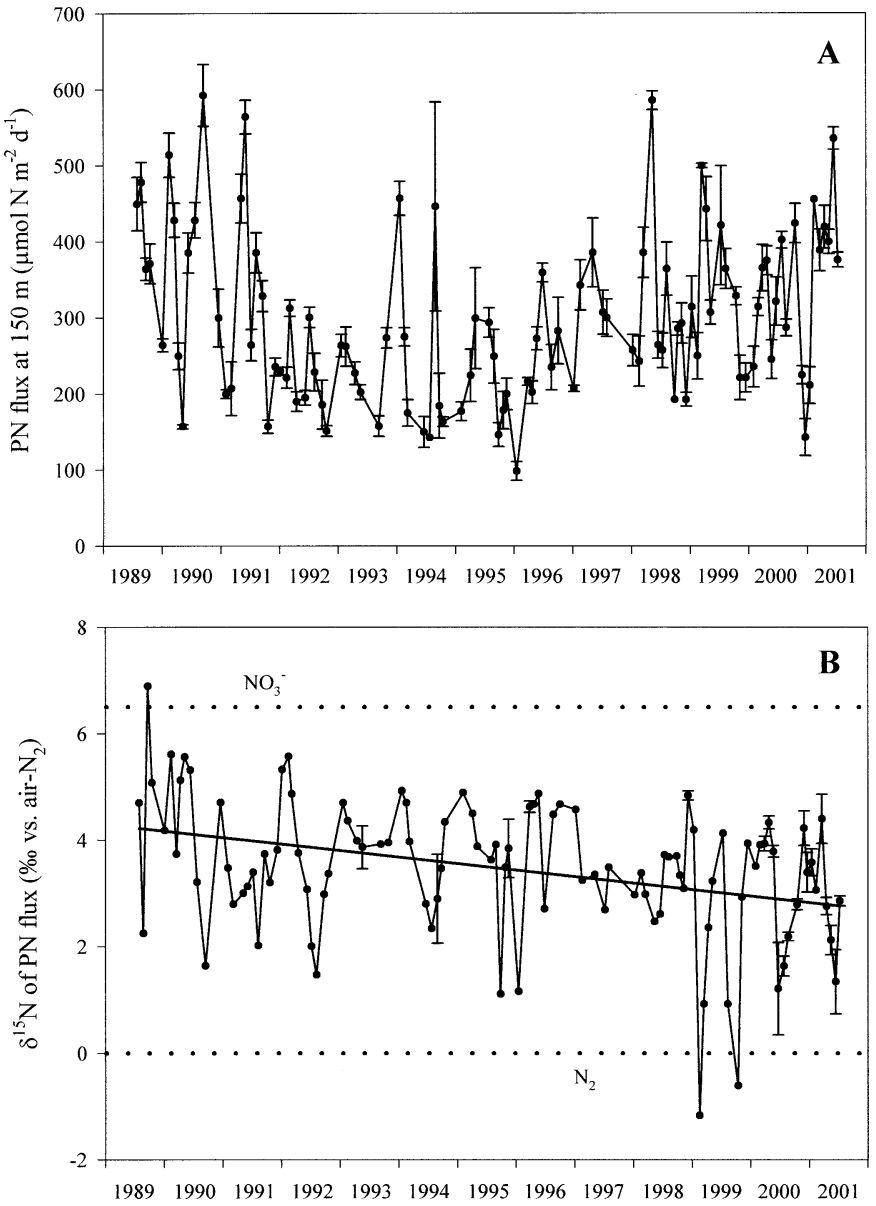

Fig. 1. Time series of particulate nitrogen (PN) export and isotopic composition determined from 150-m floating sediment trap collections at Station ALOHA. (A) PN flux $\left(\mu \mathrm{mol} \mathrm{N} \mathrm{m} \mathrm{m}^{-2} \mathrm{~d}^{-1}\right)$. Error bars represent $\pm \mathrm{SE}$ of three to six individual trap measurements. (B) Stable nitrogen isotopic composition $\left(\delta^{15} \mathrm{~N}\right)$ of trap-collected material (\%o vs. air $\mathrm{N}_{2}$ ). Error bars, where shown, represent $\pm \mathrm{SE}$ of two to three individual trap measurements. Dotted lines represent the isotopic compositions of exported PN expected when supported entirely by nitrate $(6.5 \%)$ ) or entirely by dinitrogen gas $(0 \%)$. The solid line indicates a decreasing trend determined by linear regression.

yielded a depleted signature (e.g., $\delta^{15} \mathrm{~N}-\mathrm{F}_{\mathrm{PN}}=1.34 \%$ during HOT-127, Jun 01). Flux spikes occurring in summer/fall tended to have depleted compositions when compared to winter/spring flux events. The full 12 -yr record of $\delta^{15} \mathrm{~N}-\mathrm{F}_{\mathrm{PN}}$ displays a highly significant $(P=0.0002)$ decreasing trend with time of $-0.12 \%$ o $\mathrm{yr}^{-1}(95 \%$ confidence interval $=$ -0.19 to $-0.06 \%$ o $\left.\mathrm{yr}^{-1}\right)$.

Seasonality of $N$ sources supporting $P N$ export-When binned by month, the Station ALOHA $\mathrm{F}_{\mathrm{PN}}$ dataset revealed a distinct seasonal cycle, with the highest fluxes typically occurring in May-August and the lowest fluxes occurring during November-January (Fig. 2A). The transitions between these high and low flux states appeared generally smooth, with the exception of the somewhat suppressed $\mathrm{F}_{\mathrm{PN}}$ values noted in April.
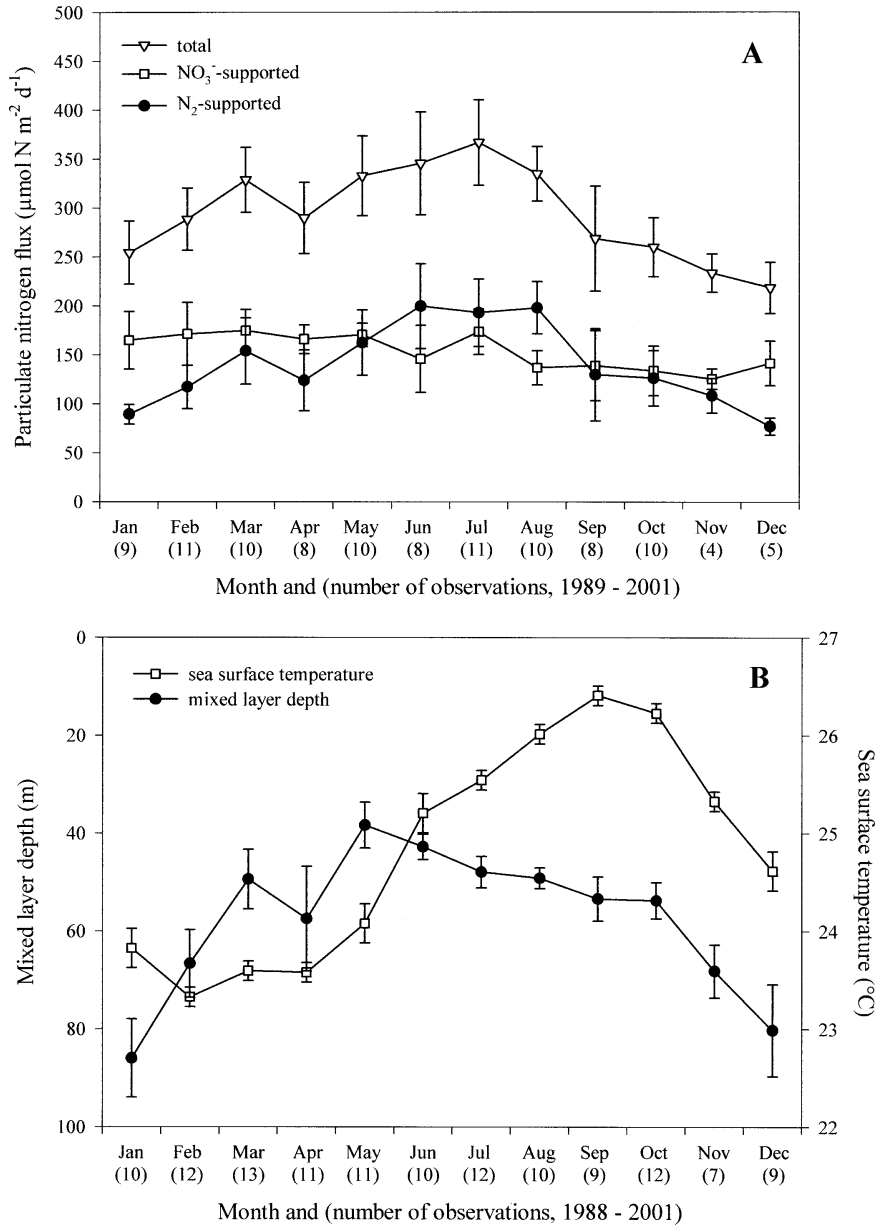

Fig. 2. Seasonality of particulate nitrogen export and upper ocean physical parameters at Station ALOHA. (A) Total, nitratesupported and dinitrogen-supported PN export flux at Station ALO$\mathrm{HA}$, binned by month. Mean values $\left(\mu \mathrm{mol} \mathrm{N} \mathrm{m}^{-2} \mathrm{~d}^{-1}\right)$ are determined from 104 floating sediment trap array deployments at $150 \mathrm{~m}$ from 1989 to 2001. Error bars represent \pm SE of measurements made during the indicated calendar month. The number of annual observations for each month is listed along the $x$-axis. (B) Mean sea surface $(0-10 \mathrm{~m})$ temperature $\left({ }^{\circ} \mathrm{C}\right)$ and mixed-layer depth $(\mathrm{m})$ at Station ALOHA, binned by month. Mixed layer is defined by the depth at which potential density first exceeds that of the surface by 0.125 . Mean values are determined from all 126 available HOT cruise data sets between October 1988 and July 2001. Error bars represent $\pm \mathrm{SE}$ of measurements made during the indicated calendar month. The number of annual observations for each month is listed along the $x$-axis.

If we assume that the export of $\mathrm{PN}$ is in balance with inputs of new nitrogen to the euphotic zone (Dugdale and Goering 1967; Eppley and Peterson 1979), then we can utilize the isotopic data to separate the total flux $\mathrm{F}_{\mathrm{PN}}$ into two components: one supported by in situ microbial $\mathrm{N}_{2}$ fixation $\left(\mathrm{F}_{\mathrm{PN}}\left[\mathrm{N}_{2}\right]\right)$ and the other by upward diffusion of $\mathrm{NO}_{3}^{-}$from the deepwater pool $\left(\mathrm{F}_{\mathrm{PN}}\left[\mathrm{NO}_{3}^{-}\right]\right)$. This approach is possible because these two major $\mathrm{N}$ sources have distinct nitrogen isotopic compositions, and because other sources of new $\mathrm{N}$, such as atmospheric deposition and horizontal advection, are believed to be negligible. The isotopic composition of $\mathrm{F}_{\mathrm{PN}}$ 
Table 1. Annual particulate nitrogen export fluxes at Station ALOHA.

\begin{tabular}{|c|c|c|c|c|c|}
\hline \multirow[b]{2}{*}{ Year } & \multirow{2}{*}{$\begin{array}{c}\text { Total PN } \\
\text { flux }(\mathrm{mmol} \\
\left.\mathrm{N} \mathrm{m}^{-2} \mathrm{yr}^{-1}\right)\end{array}$} & \multirow{2}{*}{$\begin{array}{c}\delta^{15} \mathrm{~N}-\mathrm{F}_{\mathrm{PN}}{ }^{*} \\
(\% 0 \mathrm{VS} . \\
\left.\text { air } \mathrm{N}_{2}\right)\end{array}$} & \multirow{2}{*}{$\begin{array}{c}\mathrm{N}_{2^{-}} \\
\text {supported } \\
\text { fraction } \\
(\%)\end{array}$} & \multicolumn{2}{|c|}{$\begin{array}{l}\text { Contributions to flux } \\
\left(\mathrm{mmol} \mathrm{N} \mathrm{m} \mathrm{m}^{-2} \mathrm{yr}^{-1}\right)\end{array}$} \\
\hline & & & & $\mathrm{N}_{2}$ & $\mathrm{NO}_{3}^{-}$ \\
\hline 1990 & 145 & 3.85 & 41 & 59 & 86 \\
\hline 1991 & 111 & 3.21 & 51 & 56 & 55 \\
\hline 1992 & 80 & 3.58 & 45 & 36 & 44 \\
\hline 1993 & 86 & 4.15 & 36 & 31 & 55 \\
\hline 1994 & 80 & 3.81 & 41 & 33 & 47 \\
\hline 1995 & 81 & 3.76 & 42 & 34 & 47 \\
\hline 1996 & 87 & 4.04 & 38 & 33 & 54 \\
\hline 1997 & 113 & 3.29 & 49 & 56 & 57 \\
\hline 1998 & 116 & 3.21 & 51 & 59 & 57 \\
\hline 1999 & 122 & 2.03 & 69 & 84 & 38 \\
\hline 2000 & 113 & 3.05 & 53 & 60 & 53 \\
\hline
\end{tabular}

* Flux-weighted annual average.

can be modeled by the following two-source mass balance equation (Wada and Hattori 1991).

$$
\delta^{15} \mathrm{~N}-\mathrm{F}_{\mathrm{PN}}=\left(\delta^{15} \mathrm{~N}-\mathrm{N}_{2}\right) \cdot(f)+\left(\delta^{15} \mathrm{~N}-\mathrm{NO}_{3}^{-}\right) \cdot(1-f)
$$

$f$ is the fraction of $\mathrm{F}_{\mathrm{PN}}$ supported by $\mathrm{N}_{2}$ fixation, $\delta^{15} \mathrm{~N}-\mathrm{N}_{2}=$ $0 \%$ is the theoretical $\mathrm{N}$ isotopic composition associated with $\mathrm{N}_{2}$ fixation, and $\delta^{15} \mathrm{~N}-\mathrm{NO}_{3}^{-}=6.5 \%$ is the $\mathrm{N}$ isotopic composition of nitrate diffusing across the thermocline at Station ALOHA (Karl et al. 1997). It follows that

$$
\begin{aligned}
\mathrm{F}_{\mathrm{PN}}\left[\mathrm{N}_{2}\right] & =f \cdot \mathrm{F}_{\mathrm{PN}}=\mathrm{F}_{\mathrm{PN}} \cdot\left(1-\left(\delta^{15} \mathrm{~N}-\mathrm{F}_{\mathrm{PN}} / 6.5\right)\right) \quad \text { and } \\
\mathrm{F}_{\mathrm{PN}}\left[\mathrm{NO}_{3}^{-}\right] & =(1-f) \cdot \mathrm{F}_{\mathrm{PN}}=\mathrm{F}_{\mathrm{PN}} \cdot\left(\delta^{15} \mathrm{~N}-\mathrm{F}_{\mathrm{PN}} / 6.5\right)
\end{aligned}
$$

When viewed separately, $\mathrm{F}_{\mathrm{PN}}\left[\mathrm{N}_{2}\right]$ and $\mathrm{F}_{\mathrm{PN}}\left[\mathrm{NO}_{3}^{-}\right]$displayed very different seasonal cycles (Fig. 2A). $\mathrm{F}_{\mathrm{PN}}\left[\mathrm{NO}_{3}^{-}\right]$was nearly constant regardless of the month of the year, with only a slight tendency toward higher values in winter/spring than in summer/fall. In sharp contrast to this near constancy, $\mathrm{F}_{\mathrm{PN}}\left[\mathrm{N}_{2}\right]$ varied by a factor of two from a minimum in December-January to a maximum in June-August. During the summer months, $\mathrm{F}_{\mathrm{PN}}\left[\mathrm{N}_{2}\right]$ exceeded $\mathrm{F}_{\mathrm{PN}}\left[\mathrm{NO}_{3}^{-}\right]$, whereas the converse was true during the winter. The apparent seasonality of $\mathrm{F}_{\mathrm{PN}}$ at Station ALOHA was therefore driven more by seasonality in $\mathrm{N}_{2}$ fixation than by variations in the upward flux of $\mathrm{NO}_{3}^{-}$. Monthly averaged $\mathrm{F}_{\mathrm{PN}}\left[\mathrm{N}_{2}\right]$ correlated well (inversely) with monthly averaged mixed-layer depth $\left(r^{2}=\right.$ 0.73 ) but did not correlate with monthly averaged sea surface temperature $\left(r^{2}=0.10\right.$; Fig. 2B). Conversely, a modest inverse correlation was seen between $\mathrm{F}_{\mathrm{PN}}\left[\mathrm{NO}_{3}^{-}\right]$and sea surface temperature $\left(r^{2}=0.53\right)$, but $\mathrm{F}_{\mathrm{PN}}\left[\mathrm{NO}_{3}^{-}\right]$did not correlate with mixed-layer depth $\left(r^{2}=0.02\right.$; Fig. 2).

Interannual variability of $N$ sources supporting $P N$ export-From 1990 through 2000, integrated annual PN export fluxes at Station ALOHA varied by nearly a factor of two, with a low of $80 \mathrm{mmol} \mathrm{N} \mathrm{m}^{-2} \mathrm{yr}^{-1}$ in 1994 and a high of $145 \mathrm{mmol} \mathrm{N} \mathrm{m}^{-2} \mathrm{yr}^{-1}$ in 1990 (Table 1). The overall isotopic composition of this exported $\mathrm{N}$, calculated by flux-weighting the ${ }^{15} \mathrm{~N} /{ }^{14} \mathrm{~N}$ ratios of the trap-collected $\mathrm{PN}$ over each year, varied from $2.03 \%$ in 1999 to $4.15 \%$ in 1993 . Insufficient data was available for calculating the annual average $\delta^{15} \mathrm{~N}$ $\mathrm{F}_{\mathrm{PN}}$ for the years 1989 and 2001. With these annual averages for $\mathrm{F}_{\mathrm{PN}}$ and $\delta^{15} \mathrm{~N}-\mathrm{F}_{\mathrm{PN}}$, the respective annual contributions of $\mathrm{N}_{2}$ and $\mathrm{NO}_{3}^{-}$to the support of $\mathrm{F}_{\mathrm{PN}}$ were calculated using Eqs. 3 and 4 . The results reveal that $\mathrm{N}_{2}$ fixation supplied $48 \%$ of the new nitrogen supporting export production over the 11yr period from 1990 to 2000, with $\mathrm{NO}_{3}^{-}$supporting the other $52 \%$ (Table 1). Considering individual years, $\mathrm{N}_{2}$-supported export was highest in $1999\left(84 \mathrm{mmol} \mathrm{N} \mathrm{m}^{-2} \mathrm{yr}^{-1}\right)$ and lowest in 1993 (31 mmol $\mathrm{N} \mathrm{m}^{-2} \mathrm{yr}^{-1}$ ), whereas $\mathrm{NO}_{3}^{-}$-supported export was highest in $1990\left(86 \mathrm{mmol} \mathrm{N} \mathrm{m}^{-2} \mathrm{yr}^{-1}\right)$ and lowest in 1999 (38 mmol N m $\mathrm{m}^{-2} \mathrm{yr}^{-1}$ ). The relative contribution of $\mathrm{N}_{2}$ fixation to $\mathrm{PN}$ export varied from $f=36 \%$ in 1993 to $f$ $=69 \%$ in 1999 .

Seasonality of suspended $\delta^{15} \mathrm{~N}-\mathrm{PN}$ and $>10 \mu \mathrm{m}$ phycoerythrin-The nitrogen isotopic composition of suspended $\mathrm{PN}$ in the euphotic zone $(0-175 \mathrm{~m})$ at Station ALOHA displayed coherent patterns with depth and season between May 2000 and July 2001 (Fig. 3A). In the upper $100 \mathrm{~m}$, $\delta^{15} \mathrm{~N}-\mathrm{PN}$ was always $<0.5 \%$, whereas below $100 \mathrm{~m}, \delta^{15} \mathrm{~N}-$ PN increased with depth to values of $3-5 \%$ at the base of the euphotic zone. Pronounced minima of $\delta^{15} \mathrm{~N}-\mathrm{PN}$ occurred throughout the euphotic zone in the summer months of both years, whereas relatively high values of $\delta^{15} \mathrm{~N}-\mathrm{PN}$ were maintained during the intervening winter.

The time and depth distributions of phycoerythrin in the $>10-\mu \mathrm{m}$ suspended particulate size class (PE10; Fig. 3B) generally mirrored those of isotopically depleted PN. Maximum PE10 concentrations (about 4-6 $\mu \mathrm{g} \mathrm{m}^{-3}$ ) were found in near-surface $(<50 \mathrm{~m})$ waters in June-July of both years investigated, leading the $\delta^{15} \mathrm{~N}-\mathrm{PN}$ minima by about 2 months. PE10 concentrations declined below $50 \mathrm{~m}$ to mostly unmeasurable values below $100 \mathrm{~m}$. PE10 values also fell off precipitously in near-surface waters between August and October 2000, remaining mostly unmeasurable throughout the winter and rising again in the late spring of 2001.

Seasonality of water column $N_{2}$ fixation rates-The results of ${ }^{15} \mathrm{~N}_{2}$ tracer assays on incubated water samples carried out on four HOT cruises from July 2000 to June 2001 revealed variations of $\mathrm{N}_{2}$ fixation rates with depth, time, and size class (Table 2). $\mathrm{N}_{2}$ fixation rates were highest in the mixed layer (up to $2.21 \mu \mathrm{mol} \mathrm{N} \mathrm{m}^{-3} \mathrm{~d}^{-1}$ ) and declined with depth to near-zero values at $100 \mathrm{~m}$. The relative contribution of the $<10-\mu \mathrm{m}$ size fraction decreased with increasing $\mathrm{N}_{2}$ fixation rates of the whole-water sample. Integrated $(0-100 \mathrm{~m})$ whole-water $\mathrm{N}_{2}$ fixation rates were highest in July 2000 (HOT-117) and lowest in November 2000 (HOT-120).

When depth-integrated $\mathrm{N}_{2}$ fixation rates are plotted against PE10 concentrations, a linear relationship is revealed $\left(r^{2}=\right.$ 0.87 ; Fig. 4A). The linear model implies that there is a relatively constant rate of $\mathrm{N}_{2}$ fixation attributable to the $<10$ $\mu \mathrm{m}$ size class, combined with a time-variable component that is proportional to the total phycoerythrin content of the $>10-\mu \mathrm{m}$ size class. When this model was applied to the June 2000-July 2001 PE10 dataset, predicted $\mathrm{N}_{2}$ fixation rates were generated that filled in the gaps in the record of direct rate measurements (Fig. 4B). The $\mathrm{N}_{2}$ fixation rates determined this way qualitatively compare well with $\mathrm{F}_{\mathrm{PN}}\left[\mathrm{N}_{2}\right]$ de- 

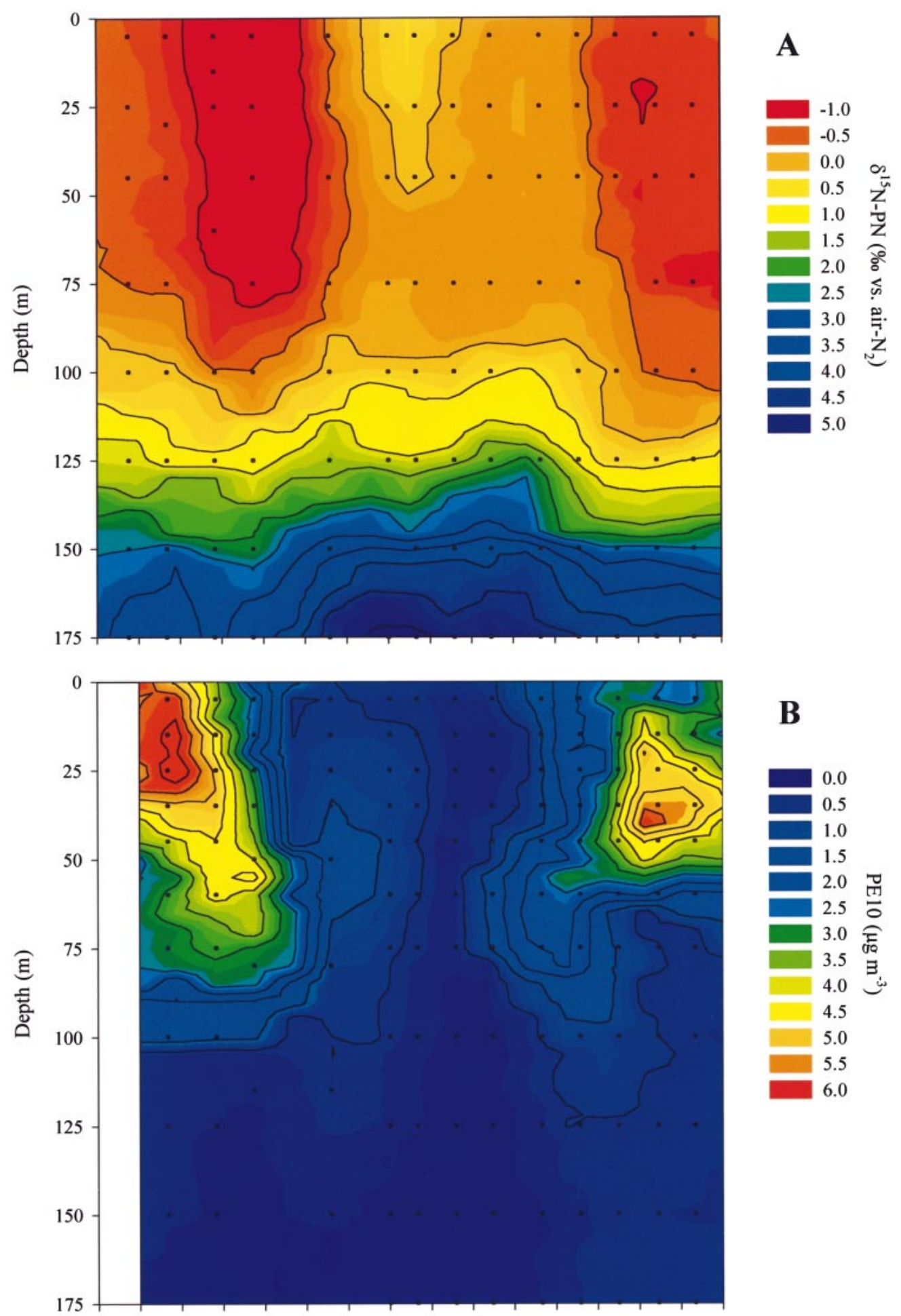

May Jun Jul Aug Sep Oct Nov Dec Jan Feb Mar Apr May Jun Jul 2000

2001

Fig. 3. (A) Time series contour plot of the nitrogen-stable isotopic composition of suspended particulate matter within the euphotic zone $(0-175 \mathrm{~m})$ at Station ALOHA between May 2000 and July 2001. Color spectrum indicates $\delta^{15} \mathrm{~N}-\mathrm{PN}\left(\%\right.$ o vs. air $\left.\mathrm{N}_{2}\right)$ ranging from depleted (red-orange hues) to enriched (blue-violet hues) values. Dots indicate samples collected. (B) Time series contour plot of phycoerythrin concentration in the $>10-\mu \mathrm{m}$ size fraction (PE10) of suspended particulate matter in the euphotic zone at Station ALOHA between June 2000 and July 2001. Color spectrum indicates PE10 $\left(\mu \mathrm{g} \mathrm{m}^{-3}\right)$ ranging from high (red-orange hues) to low (blue-violet hues) concentrations. Dots indicate samples collected. 
Table 2. Water column nitrogen fixation rates at Station ALOHA measured with ${ }^{15} \mathrm{~N}_{2}$ tracer technique using bottle-collected samples and on-deck simulated in situ incubations.

\begin{tabular}{|c|c|c|c|c|}
\hline \multirow[b]{2}{*}{ Cruise } & \multirow[b]{2}{*}{ Date } & \multirow[b]{2}{*}{ Depth (m) } & \multicolumn{2}{|c|}{$\begin{array}{l}\mathrm{N}_{2} \text { fixation rate } \\
\left(\mu \mathrm{mol} \mathrm{N} \mathrm{m}^{-3} \mathrm{~d}^{-1}\right)\end{array}$} \\
\hline & & & Whole & $<10 \mu \mathrm{m}$ \\
\hline \multirow[t]{6}{*}{ HOT-117 } & $26 \mathrm{Jul} 00$ & 4 & 1.15 & —* \\
\hline & & 14 & 2.21 & - \\
\hline & & 24 & 1.59 & - \\
\hline & & 35 & 1.82 & 0.16 \\
\hline & & 43 & 1.74 & 0.24 \\
\hline & & 58 & 1.01 & - \\
\hline \multirow[t]{5}{*}{ HOT-120 } & 30 Nov 00 & 5 & 0.90 & 0.55 \\
\hline & & 24 & 0.70 & 0.26 \\
\hline & & 44 & 0.29 & 0.13 \\
\hline & & 73 & 0.24 & 0.09 \\
\hline & & 98 & 0.00 & 0.00 \\
\hline \multirow[t]{7}{*}{ HOT-124 } & 21 Mar 01 & 4 & 1.00 & - \\
\hline & & 24 & 0.95 & - \\
\hline & & 24 & 1.03 & - \\
\hline & & 24 & 0.78 & - \\
\hline & & 43 & 0.93 & - \\
\hline & & 73 & 0.65 & - \\
\hline & & 97 & 0.08 & - \\
\hline \multirow[t]{6}{*}{ HOT-127 } & 14 Jun 01 & 5 & 1.30 & 0.37 \\
\hline & & 24 & 1.43 & 0.43 \\
\hline & & 25 & 1.07 & 0.44 \\
\hline & & 46 & 0.54 & 0.46 \\
\hline & & 74 & 0.40 & 0.30 \\
\hline & & 100 & 0.07 & 0.07 \\
\hline
\end{tabular}

*-, not determined.

termined from $\delta^{15} \mathrm{~N}-\mathrm{F}_{\mathrm{PN}}$ (Fig. 4C), in that maximum rates occur in July 2000 and June 2001 and minimum rates in November 2000-January 2001. However, the $\mathrm{N}_{2}$ fixation rates determined from water column measurements yield values that are only $18-55 \%$ of the sediment trap-derived $\mathrm{F}_{\mathrm{PN}}\left[\mathrm{N}_{2}\right]$ values (mean $=30 \%, \mathrm{SE}=4 \%$ ).

\section{Discussion}

PN export flux and its stable isotopic composition-Particle export in the sea is traditionally considered to vary with new production, increasing with the input of $\mathrm{NO}_{3}^{-}$from deep water during winter/spring mixing that penetrates through the nitracline. At Station ALOHA, mixing to the depth of the nitracline (115 $\pm 18 \mathrm{~m}$; Dore and Karl 1996) is a rare occurrence, and large nitrate-supported vernal blooms of phytoplankton are not observed. $\mathrm{NO}_{3}^{-}$input to the euphotic zone appears to be mainly through diffusive and mesoscale eddy-related processes; top-down wind-driven mixing of the water column seldom deepens the mixed layer below 100 $\mathrm{m}$, and measurable increases of $\mathrm{NO}_{3}^{-}$concentrations in surface waters are infrequent (Karl 1999). Nevertheless, export flux at this site exhibits considerable variability on a variety of timescales (Fig. 1). It is possible that episodic nutrient inputs, seldom observed during the monthly sampling program, contribute significantly to the variability of the export flux (Letelier et al. 2000). Another potentially important source of variability in export, one that has not yet been
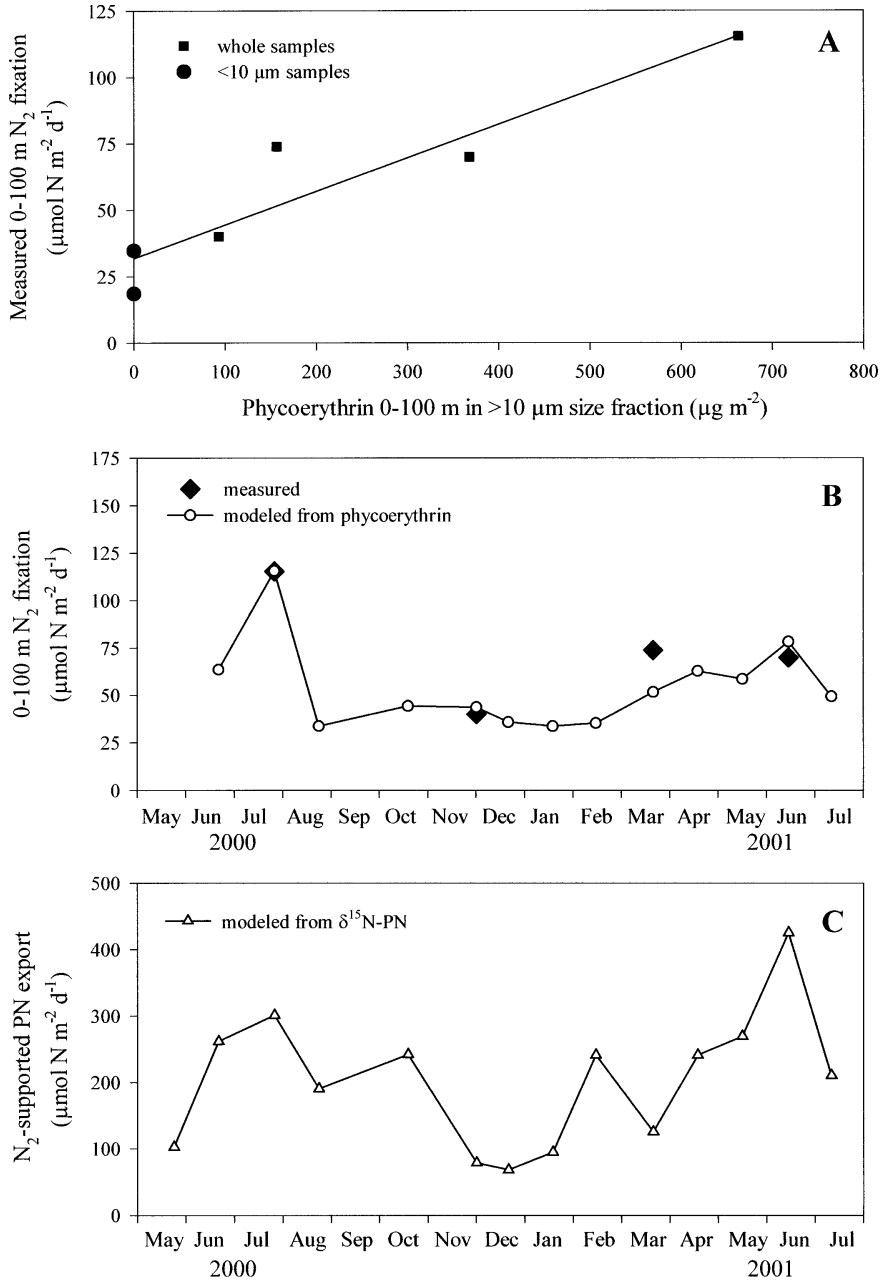

Fig. 4. Measured and modeled depth-integrated $(0-100 \mathrm{~m})$ rates of nitrogen fixation $\left(\mu \mathrm{mol} \mathrm{N} \mathrm{m} \mathrm{N}^{-2} \mathrm{~d}^{-1}\right)$ at Station ALOHA from May 2000 through July 2001. (A) Relationship between integrated $\mathbf{N}_{2}$ fixation rates (whole and $<10-\mu \mathrm{m}$ data) measured with the ${ }^{15} \mathrm{~N}_{2}$ tracer method and integrated $(0-100 \mathrm{~m})$ phycoerythrin concentration within the $>10-\mu \mathrm{m}$ size fraction of suspended particulate matter (PE10). Linear regression equation is $Y=31.8+(0.126 X)$. (B) Integrated $\mathrm{N}_{2}$ fixation rates modeled from PE10 measurements using the linear regression derived in panel $\mathrm{A}$. The integrated whole-water $\mathrm{N}_{2}$ fixation rate measurements are also shown for comparison. PE10 samples were not collected during May 2000. (C) $\mathrm{N}_{2}$-supported PN export flux derived from PN and $\delta^{15} \mathrm{~N}-\mathrm{PN}$ measurements of floating sediment trap collections at $150 \mathrm{~m}$. Note the difference in the $y$ axis scale between panels $\mathrm{C}$ and $\mathrm{B}$ : $\mathrm{N}_{2}$ fixation rate measurements based on bottle-collected samples account for only about $30 \%$ of the $\mathrm{N}_{2}$-supported PN export estimated from floating sediment traps.

assessed over long time periods in the subtropical North Pacific, is the nitrogen-fixing activity of diazotrophs.

We have employed a stable isotopic mass balance of sinking $\mathrm{PN}$ in order to deconvolute the export flux into $\mathrm{N}_{2}$ fixation-supported and $\mathrm{NO}_{3}^{-}$-supported components. Some important assumptions are inherent in this approach. First, we assume that over timescales of months to years, inputs of new $\mathrm{N}$ balance exported $\mathrm{N}$ (i.e., accumulations or depletions of fixed $\mathrm{N}$ are assumed to be small compared to the fluxes). This assumption is supported by field data. Multiyear ac- 
cumulations of both dissolved organic nitrogen (DON; Church et al. 2002) and PN (Hebel and Karl 2001) have been observed within the euphotic zone at Station ALOHA, but their magnitudes (30 and $<5 \mu \mathrm{mol} \mathrm{N} \mathrm{m}^{-2} \mathrm{~d}^{-1}$, respectively) are small compared to the PN flux (Fig. 1).

Second, we assume that $\mathrm{N}$ fluxes other than the upward flux of $\mathrm{NO}_{3}^{-}$, the downward flux of $\mathrm{PN}$, and nitrogen fixation are negligible. These minor fluxes include atmospheric deposition, horizontal (isopycnal) transport of DON, downward diffusion of DON, and the active downward transport of $\mathrm{N}$ by diel-migrant zooplankton. Net atmospheric deposition of nitrogen oxides and ammonium to the North Pacific has been recently estimated at only approximately $22 \mu \mathrm{mol} \mathrm{N} \mathrm{m} \mathrm{N}^{-2} \mathrm{~d}^{-1}$ (Deutsch et al. 2001), whereas a lack of regional DON gradients precludes significant horizontal transport of DON into the study area (Abell et al. 2000). Vertical DON gradients are only about $10 \%$ of the vertical $\mathrm{NO}_{3}^{-}$gradients (Karl et al. 2001); hence, downward diffusion of DON can at most balance only a few percent of the nitrogen imports. The zooplankton flux has been estimated at $45 \mu \mathrm{mol} \mathrm{N} \mathrm{m}{ }^{-2} \mathrm{~d}^{-1}$ (AlMutairi and Landry 2001), which is also small compared to the major fluxes (Fig. 1).

Third, we assume constant isotopic compositions for the two $\mathrm{N}$ supply terms of $\delta^{15} \mathrm{~N}-\mathrm{N}_{2}=0 \% 0$ and $\delta^{15} \mathrm{~N}-\mathrm{NO}_{3}^{-}=$ $6.5 \%$. The $\delta^{15} \mathrm{~N}$ of upwardly diffusing $\mathrm{NO}_{3}^{-}$can vary with time at this site because of remineralization of the exported PN within the thermocline and potentially because of the influence of infrequent eddies carrying denitrified waters with a high $\delta^{15} \mathrm{~N}-\mathrm{NO}_{3}^{-}$from the eastern tropical North Pacific (Lukas and Santiago-Mandujano 2001). However, the few measurements of subsurface and intermediate water $\delta^{15} \mathrm{~N}$ $\mathrm{NO}_{3}^{-}$reported from the central North Pacific average approximately 6.5\%o (Cline and Kaplan 1975; Liu and Kaplan 1989) and are consistent with recent measurements made further east but below the oxygen minimum zone (Voss et al. 2001). No net isotopic fractionation occurs during uptake of this nitrate by phytoplankton because the concentration is drawn to zero (i.e., the reaction goes to completion). The $\delta^{15} \mathrm{~N}$ of atmospheric $\mathrm{N}_{2}$ is defined as $0 \%$. A slight equilibrium fractionation results in dissolved $\mathrm{N}_{2}$ gas at the sea surface being enriched about $0.6 \%$ when compared to atmospheric $\mathrm{N}_{2}$ (Cline and Kaplan 1975). Little or no $\mathrm{N}$ isotopic fractionation is thought to occur during the process of $\mathrm{N}_{2}$ fixation (Hoering and Ford 1960; Delwiche and Steyn 1970), but a slight fractionation would bring the isotopic composition of the $\mathrm{N}$ fixed back toward its original atmospheric value of $0 \%$. Although field samples of PN and Trichodesmium have been collected with $\delta^{15} \mathrm{~N}=-1.5 \%$ or less (Wada and Hattori 1976; Minagawa and Wada 1986; Saino and Hattori 1987; Fig. 3A), the $\mathrm{N}$ isotopic composition of these samples could have been reduced below that associated with $\mathrm{N}_{2}$ fixation through biological uptake of recycled ammonium (Checkley and Miller 1989). Furthermore, the extrema of our $\delta^{15} \mathrm{~N}-\mathrm{F}_{\mathrm{PN}}$ data fall quite close to the isotopic composition limits of $0 \%$ and $6.5 \%$ imposed by the model, giving us greater confidence in these end members.

Fourth and finally, we assume that our sediment traps accurately collect the export flux without introducing any isotopic fractionation or other isotopic biases. Although it has been suggested that sediment traps might underestimate total sinking particle flux during high-flux periods (Benitez-Nelson et al. 2001), these high-flux regimes are usually associated with elevated $\mathrm{N}_{2}$ fixation (Figs. 1, 2); hence, there could be a tendency here to underestimate absolute $\mathrm{N}_{2}$ fixation rates. Nevertheless, the relative contributions of $\mathrm{N}_{2}$ fixation and the $\mathrm{NO}_{3}^{-}$flux to export production can only be affected if quantitatively important sinking particles of fundamentally different $\delta^{15} \mathrm{~N}$ are being "missed" by the traps or if isotopically extreme live organisms (zooplankton "swimmers") are entering the traps. The undercollection of specific classes of isotopically extreme particles, although possible, seems less likely than a simple undercollection of the bulk sinking material. Zooplankton swimmers small enough to pass through our $333-\mu \mathrm{m}$ postcollection processing mesh would likely be primary consumers; these organisms should have $\delta^{15} \mathrm{~N}$ signatures that are $3.4 \pm 1.1 \%$ o higher than their food (Minagawa and Wada 1984). Thus, small zooplankton, such as the Trichodesmium-grazing harpactacoid copepod Macrosetella gracilis, should have nitrogen isotopic compositions nearly the same as that of the bulk trap-collected material (Fig. 1B); hence, their presence in the collections would have little effect on the derivation of the relative contributions of $\mathrm{N}_{2}$ and $\mathrm{NO}_{3}^{-}$to the export flux. Similarly, even though the "other" minor fluxes and accumulations of fixed $\mathrm{N}$ could combine to a total that is not negligible, as assumed, these fluxes would have to have $\delta^{15} \mathrm{~N}$ values far from those of the collected particles in order to substantially influence the derived $\mathrm{N}_{2}$ versus $\mathrm{NO}_{3}^{-}$relative contributions.

The results of the $\delta^{15} \mathrm{~N}-\mathrm{F}_{\mathrm{PN}}$ measurements confirm that although occasional $\mathrm{NO}_{3}^{-}$-supported flux events occur (Fig. 1), large springtime increases in $\mathrm{NO}_{3}^{-}$-supported export are not a characteristic feature of the $\mathrm{N}$ cycle at Station ALOHA (Fig. 2). The small seasonal signal observed in $\mathrm{F}_{\mathrm{PN}}\left[\mathrm{NO}_{3}^{-}\right]$ can be attributed to winter/spring cooling of the surface ocean and an attendant decrease in water column stability, enhancing eddy-diffusive transport of $\mathrm{NO}_{3}^{-}$into the lower euphotic zone, combined with increasing spring light penetration. The lack of a correlation between $\mathrm{F}_{\mathrm{PN}}\left[\mathrm{NO}_{3}^{-}\right]$and mixed-layer depth confirms that top-down mixing rarely entrains significant amounts of $\mathrm{NO}_{3}^{-}$from the nitracline. On the other hand, $\mathrm{F}_{\mathrm{PN}}\left[\mathrm{N}_{2}\right]$ is strongly (negatively) correlated with mixed-layer depth (Fig. 2). Deepening mixed layers are expected to decrease $\mathrm{N}_{2}$ fixation for at least two reasons: (1) the net flux of light energy to cells is reduced, and (2) the mixed layer concentration of atmospherically deposited iron is diluted. Because $\mathrm{N}_{2}$ fixation demands large amounts of both energy and bioavailable iron, the reduction of these two factors reduces $\mathrm{N}_{2}$ fixation activity (Karl et al. 2002). Furthermore, the interaction of high light and high iron can enhance iron bioavailability (Barbeau et al. 2001); hence, shallow mixed layers present ideal conditions for diazotrophy at Station ALOHA.

Seasonality of $\mathrm{N}_{2}$ fixation-The sediment trap record reveals that $\mathrm{N}_{2}$ fixation is maximal in the summer months, in concert with maximum water column stratification (Fig. 2). When the water column suspended PN is examined over an annual cycle, its $\delta^{15} \mathrm{~N}$ is seen to decrease in summer and increase in winter, consistent with the sediment trap record 
(Fig. 3). Among the phytoplankton, only cyanobacteria, cryptophytes, and a few rhodophytes contain the photosynthetic accessory pigment phycoerythrin (Stewart and Farmer 1984). In subtropical ocean waters, the large diazotrophic cyanobacterium Trichodesmium is expected to be the principal contributor to phycoerythrin fluorescence within the $>10-\mu \mathrm{m}$ size class (Moreth and Yentsch 1970), although the endosymbiotic cyanobacterium Richelia can also appear within this size class by virtue of its diatom hosts. The biomass of these "large" diazotrophs at Station ALOHA, as indicated by the estimated PE10 concentration, rises in parallel with the observed decline in $\delta^{15} \mathrm{~N}-\mathrm{F}_{\mathrm{PN}}$ and $\delta^{15} \mathrm{~N}-\mathrm{PN}$ (Fig. 3 ), suggesting an important role for the large size class in the seasonal cycle of $\mathrm{N}_{2}$ fixation. Although Trichodesmium appears to be limited to regions with surface waters $>20^{\circ} \mathrm{C}$ (Marumo and Asaoka 1974; Carpenter 1983), low temperature per se does not restrict the growth of $\mathrm{N}_{2}$-fixing organisms (Karl et al. 2002). The PE10 results reveal that large, phycoerythrin-containing organisms reach their peak abundance well before the seasonal temperature maximum (Figs. 2, 3), lending evidence that factors other than temperature control their growth. The combined water column and trap data sets suggest that stratification of the water column, in conjunction possibly with April/May inputs of iron via atmospheric deposition (Donaghay et al. 1991), are potential controlling factors.

Direct water column measurements of $\mathrm{N}_{2}$ fixation rates using ${ }^{15} \mathrm{~N}_{2}$ tracer incubations reveal patterns with depth and season that are similar to those of water column PE10 and $\delta^{15} \mathrm{~N}-\mathrm{PN}$ (Table 2; Fig. 3). Most of the measured activity is in the upper $50 \mathrm{~m}$, consistent with a strong light energy dependence of $\mathrm{N}_{2}$ fixation. Also, $\mathrm{N}_{2}$ fixation activity within the $>10-\mu \mathrm{m}$ size class displays seasonality consistent with the summer rise and winter decline of large diazotrophs demonstrated by the PE10 record (Fig. 4), consistent with results from the Atlantic that reveal large variations in Trichodesmium biomass but relatively constant $\mathrm{N}_{2}$ fixation per unit biomass (Orcutt et al. 2001). It appears that while large diazotrophs only thrive when stratification reduces the mixed-layer depth to about $50 \mathrm{~m}$ or less (Figs. 2, 3), small $\mathrm{N}_{2}$ fixers can remain present and active year-round. The relative importance of large versus small diazotrophs to the $\mathrm{N}$ budget is therefore likely to be dependent on the effects of physical forcing on the large size class.

Taking into account all four of these data sets $\left(\delta^{15} \mathrm{~N}-\mathrm{F}_{\mathrm{PN}}\right.$, $\delta^{15} \mathrm{~N}-\mathrm{PN}, \mathrm{PE} 10$, and ${ }^{15} \mathrm{~N}_{2}$ assimilation), the following seasonal picture emerges. With increasing water column stratification and light intensity (and possibly iron deposition) during the spring (Mar-May; Fig. 2), "large" diazotrophic populations increase in abundance. These organisms reach peak abundance, and hence peak total areal $\mathrm{N}_{2}$ fixation rates, in June-July (Figs. 3, 4). Some of the newly fixed PN is exported rapidly via cell aggregation and sinking, which can result in a large flux "event" with low $\delta^{15} \mathrm{~N}$ (Fig. 1). Some of the diazotroph $\mathrm{N}$ enters the microbial loop via excretion of DON and ammonium (Glibert and Bronk 1994) and by autolysis of cyanobacterial cells with subsequent uptake of DON by microheterotrophs. Fixed $\mathrm{N}$ that is remineralized in situ can be assimilated by other phytoplankton as well. Grazing zooplankton "repackage" some of the $\mathrm{N}$ into fecal pel- lets or pass it up the food chain to larger consumers. The $\mathrm{PN}$ that is exported from the grazing pathway is enriched in ${ }^{15} \mathrm{~N}$, whereas ammonium excreted by zooplankton is depleted in ${ }^{15} \mathrm{~N}$ compared to the animals' food (Minagawa and Wada 1984; Checkley and Miller 1989). Because this isotopically depleted ammonium is reincorporated by phytoplankton into suspended PN, euphotic zone $\delta^{15} \mathrm{~N}-\mathrm{PN}$ continues to "lighten" during August-September (Fig. 3A), even though at this time diazotroph biomass is decreasing (Fig. 3B) and the sinking PN flux is growing isotopically "heavier" (Figs. 1, 2). In the fall (Sep-Nov), declining light levels and deepening mixed layers inhibit the growth of the large size class of diazotrophs (Fig. 3B); hence, areal $\mathrm{N}_{2}$ fixation rates decline (Figs 2,4), and $\delta^{15} \mathrm{~N}-\mathrm{PN}$ begins to rise as the fractional contribution of $\mathrm{NO}_{3}^{-}$to new production increases (Fig. 3). Increased vertical $\mathrm{NO}_{3}^{-}$flux during winter (Dec-Feb) results in an increase in $\delta^{15} \mathrm{~N}-\mathrm{PN}$, especially below $100 \mathrm{~m}$. Because the $\delta^{15} \mathrm{~N}-\mathrm{PN}$ in the upper $100 \mathrm{~m}$ remains very low $(<0.5 \%$ o throughout the winter, it is clear that mixing does not penetrate the nitracline (Fig. 3) and that new production in the upper euphotic zone is supported almost entirely by $\mathrm{N}_{2}$ fixation. However, because the $\delta^{15} \mathrm{~N}-\mathrm{F}_{\mathrm{PN}}$ data reveal that roughly half the annual PN export is derived from $\mathrm{NO}_{3}^{-}$(Table 1), annual export of PN from the lower $(>100 \mathrm{~m})$ euphotic zone must be roughly equivalent to export from the upper $100 \mathrm{~m}$ and must be almost entirely supported by $\mathrm{NO}_{3}^{-}$.

Incubation versus trap-derived rates-It is important to point out that our ${ }^{15} \mathrm{~N}_{2}$ incubation data yield absolute wholewater rates that are considerably less than those determined from the sediment trap $\mathrm{N}$ isotope record (Fig. 4). The incubation results are very likely underestimates of the true in situ rates, largely because of undersampling issues where large diazotrophs are concerned. Direct comparisons of our results to parallel whole and $<10-\mu \mathrm{m}$ size-fractionated $\mathrm{N}_{2}$ fixation measurements made by other investigators during HOT-117 (Jul 00) reveal nearly identical rates (Zehr et al. 2001; J. Montoya pers. comm.). In addition, our measured $\mathrm{N}_{2}$ fixation rates are similar in magnitude to earlier results from whole-water incubations using the acetylene reduction technique in the same region (Mague et al. 1977). Therefore, it is likely that our incubation data accurately reflect the $\mathrm{N}_{2}$ fixation rates within the incubated samples. However, bottlecollected samples are probably not representative of the in situ diazotroph populations or activities. Much of the potential for diazotrophy in the NPSG lies within relatively rare large organisms, consortia and aggregates, such as Trichodesmium colonies and Hemiaulus and Rhizosolenia diatom mats with their Richelia endosymbionts (Villareal 1992; Letelier and Karl 1996). These "particles" are almost certainly undersampled by water bottles; in contrast, small free-living unicells are more likely to be sampled quantitatively in this manner. In addition, the $\mathrm{N}_{2}$ fixation activity of consortia in situ might be greatly reduced upon sampling because of disruption of aggregate structure, cell-cell interactions, and chemical gradients (Martínez et al. 1983; Paerl 1990; Letelier and Karl 1998). Furthermore, the potential excretion of DON by Trichodesmium, which could possibly represent as much as half of the gross rate of $\mathrm{N}_{2}$ fixation (Glibert and Bronk 1994), is not measured by our ${ }^{15} \mathrm{~N}_{2}$ tracer technique. 
Also, because of episodic bloom phenomena (e.g., Trichodesmium; Karl et al. 1992), undersampling in time can lead to underestimates of $\mathrm{N}_{2}$ fixation rates; bottle incubations give a snapshot in time, whereas the trap-collected isotopes integrate over periods of days to weeks at least, and possibly longer.

Our trap-derived annual $\mathrm{N}_{2}$ fixation rates agree well with those required by recent Pacific Ocean $\mathrm{N}$ budget calculations, lending further support to their accuracy. Deutsch et al. (2001) have examined the fixed nitrogen budget of the Pacific based on nutrient fields analyzed during the World Ocean Circulation Experiment (WOCE) global survey (1991-1996). They concluded that $\mathrm{N}_{2}$ fixation in the Pacific should contribute $59 \pm 14 \mathrm{Tg} \mathrm{N} \mathrm{yr}^{-1}$ in order to balance the budget. On an areal basis, assuming $\mathrm{N}_{2}$ fixation in the Pacific is confined between $30^{\circ} \mathrm{S}$ and $30^{\circ} \mathrm{N}$, the required flux amounts to $39 \pm 9 \mathrm{mmol} \mathrm{N} \mathrm{m}{ }^{-2} \mathrm{yr}^{-1}$. This value is within the range of our annual $\mathrm{F}_{\mathrm{PN}}\left[\mathrm{N}_{2}\right]$ estimates (Table 1) and is remarkably similar to our mean $\mathrm{F}_{\mathrm{PN}}\left[\mathrm{N}_{2}\right]$ during the 1990 1996 time period $\left(40 \mathrm{mmol} \mathrm{N} \mathrm{m}^{-2} \mathrm{yr}^{-1}\right)$. Given all of the above considerations, it seems that although ${ }^{15} \mathrm{~N}_{2}$ incubation measurements on bottle-collected samples as carried out here are valuable for elucidating patterns of $\mathrm{N}_{2}$ fixation with time, depth, and size class, they are inadequate for accurately assessing the overall in situ rates of $\mathrm{N}_{2}$ fixation in the NPSG.

Climate and sources of new $N$ in the NPSG-The surface waters of the NPSG, once thought of as a monotonous and unchanging oceanic "desert," are now recognized as home to a dynamic ecosystem exhibiting seasonal, interannual, and decadal timescales of variability (Karl 1999). Variations in climate appear to play an important role in regulating this ecosystem variability. Karl et al. (1995) revealed a possible connection between tropical Pacific climate and NPSG ecosystem properties; major changes in a variety of these properties had occurred coincidently with the development of the El Niño-Southern Oscillation (ENSO) event of 1991-1992. These authors hypothesized that the changes were driven by an ENSO-associated extended period of calm weather in the NPSG, which increased upper-ocean stratification, reduced the input of nitrate from below, and thereby selected for nitrogen-fixing organisms. Among the many ecosystem shifts observed was a decline in the export flux of organic matter from the euphotic zone. We can now revisit the effect of ENSO on particulate export flux armed with $12 \mathrm{yr}$ of $\mathrm{F}_{\mathrm{PN}}$ and $\delta^{15} \mathrm{~N}-\mathrm{F}_{\mathrm{PN}}$ data.

When examined along with the Southern Oscillation Index (SOI; Troup 1965), a tropical climate index that tracks the ENSO phenomenon, the total export of PN has continued to demonstrate a coherence with the ENSO patterns (Fig. 5A). Cross-correlation analysis of these smoothed (11-month running mean) records reveals a 10-month offset; that is, $\mathrm{F}_{\mathrm{PN}}$ in the NPSG appears to respond to ENSO fluctuations a bit less than a year after they occur. Positive SOI (La Niña) conditions tend to correlate with periods of high $\mathrm{F}_{\mathrm{PN}}$, and negative (El Niño) conditions tend to correlate with reduced export flux, with an overall correlation coefficient of $r=0.42$. These results could be considered consistent with the hypothesis that increased upper ocean stratification caused by El Niño conditions reduces the input of new $\mathrm{NO}_{3}^{-}$, hence
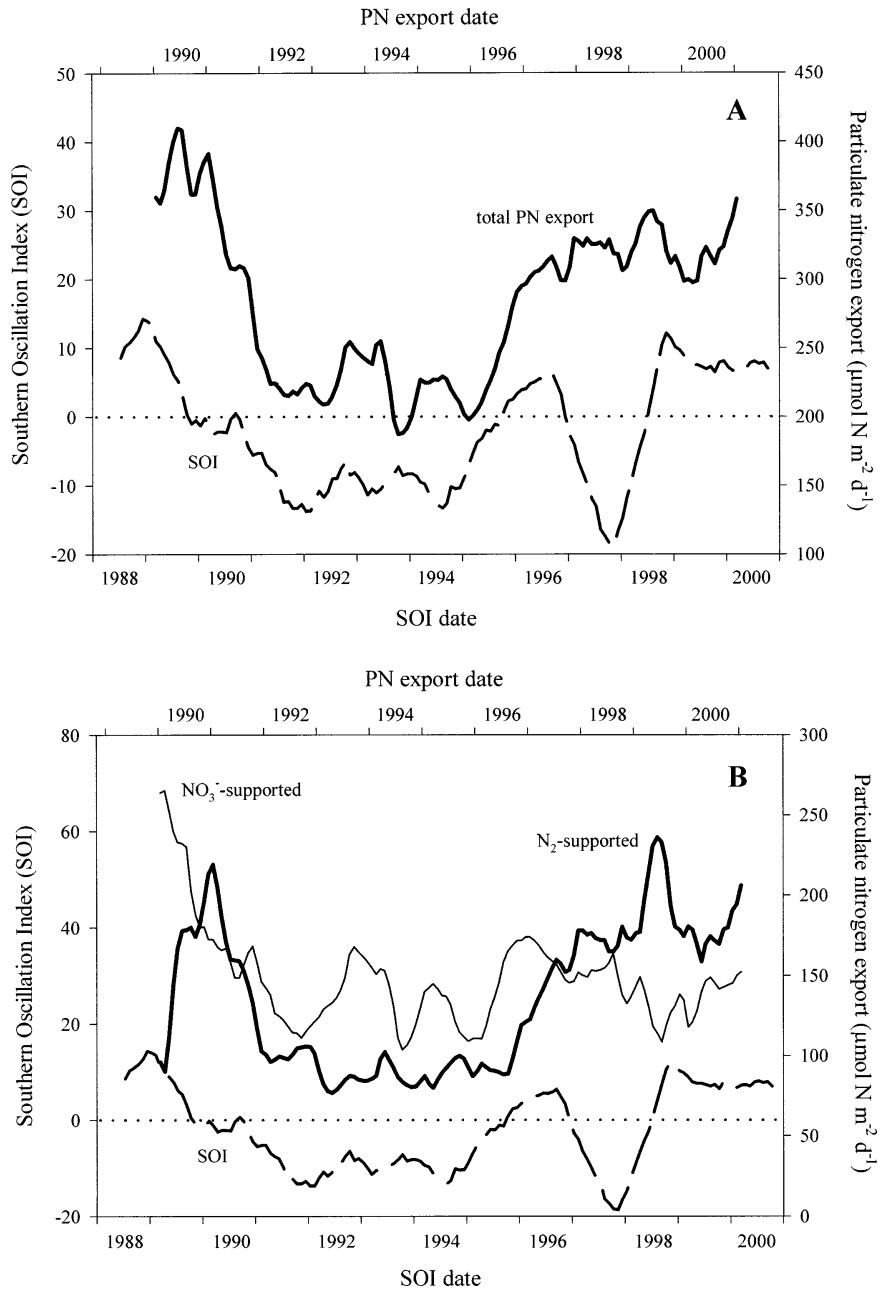

Fig. 5. Correlation between PN export at Station ALOHA and the El Niño-Southern Oscillation climate phenomenon. (A) Time series of total PN export at Station ALOHA and of the Troup Southern Oscillation Index (SOI). Each curve has been smoothed using an 11-month running mean of monthly data, after linear interpolation as necessary in the PN export data set. The $x$-axes have been offset by 10 months in order to emphasize the best cross-correlation (i.e., the fluctuations in PN export at Station ALOHA best correlate with fluctuations in the SOI observed 10 months earlier). (B) Time series comparison of PN export and SOI with a 10-month time lag as in panel A, except that PN flux has been separated into nitratesupported and dinitrogen-supported components.

enhancing recycling pathways and reducing export (Karl et al. 1995).

When we deconvolute the $\mathrm{F}_{\mathrm{PN}}$ record into $\mathrm{N}_{2}$ fixation-supported and $\mathrm{NO}_{3}^{-}$-supported components, however, we see a more complex picture: the two export terms appear to respond differently to changes in the SOI (Fig. 5B). $\mathrm{F}_{\mathrm{PN}}\left[\mathrm{NO}_{3}^{-}\right]$declined sharply as La Niña gave way to El Niño conditions from 1989 to 1992 and has not since regained its former strength. $\mathrm{F}_{\mathrm{PN}}\left[\mathrm{N}_{2}\right]$, on the other hand, rose to a maximum during 1990 and just as swiftly declined to its former level by 1992, then rose again from 1996 to 1998. With a 10-month lag period, fluctuations in $\mathrm{F}_{\mathrm{PN}}\left[\mathrm{N}_{2}\right]$ tend to correlate better $(r=0.45)$ with the SOI than do fluctuations in 
$\mathrm{F}_{\mathrm{PN}}\left[\mathrm{NO}_{3}^{-}\right](r=0.12)$. This result implies that $\mathrm{F}_{\mathrm{PN}}\left[\mathrm{N}_{2}\right]$ is the dominant factor responsible for the correlation of $\mathrm{F}_{\mathrm{PN}}$ with the SOI.

Reductions in stratification during La Niña periods might serve to enhance vertical transport of $\mathrm{NO}_{3}^{-}$, but over the past decade, this destratification has not been sufficiently intense to mix deeply into the nitracline. The very high $\mathrm{F}_{\mathrm{PN}}\left[\mathrm{NO}_{3}^{-}\right]$ at the beginning of this data record suggests that such deep mixing might have occurred before the HOT observational program was fully implemented. The timing of the abrupt drop in $\mathrm{F}_{\mathrm{PN}}\left[\mathrm{NO}_{3}^{-}\right]$is consistent with a switch in the climate regime of the North Pacific, as indicated both by the SOI (Fig. 5) and the Pacific Decadal Oscillation Index (PDOI; Mantua et al. 1997; Minobe 2000). This latter index, like the SOI, is used to describe climate oscillations in the Pacific, but unlike ENSO, the climatic fingerprints of the Pacific Decadal Oscillation (PDO) are seen mainly in the North Pacific and are less evident in the tropics. The PDO also differs from ENSO in that its "events" last 20-30 yr as opposed to the 6-18 months duration typically seen for El Niño events (Hare and Mantua 2000). Station ALOHA is located such that effects of both climate phenomena are likely to be observed and to have complex interactions. PDOI fluctuations are strongest in two periodicities: a 50-70-yr cycle and a 15-25-yr cycle (Minobe 1999). During the winter of 1988-1989, a sudden reversal (positive to negative) of the 15-25-yr periodicity of the PDOI signaled a "minor regime shift" (Minobe 2000) in North Pacific climate. At the same time, a declining SOI indicated a transition from a La Niña to an El Niño state in the tropics. This simultaneous change in Pacific climate indices heralded the end of a highenergy period of mixing in the NPSG (Karl 1999), just as the HOT program was getting started. The strong winter Aleutian low-pressure system that had been forcing warm air toward Alaska and cold air southward since 1977 weakened, resulting in warming of the sea surface over much of the NPSG and a reduction in trade winds (Karl 1999; Hare and Mantua 2000). It could be that a coherence between the positive states of the PDO and ENSO is required in order to drive mixed layers at Station ALOHA deep enough to entrain significant amounts of nitrate from below.

$\mathrm{F}_{\mathrm{PN}}\left[\mathrm{N}_{2}\right]$, in contrast to $\mathrm{F}_{\mathrm{PN}}\left[\mathrm{NO}_{3}^{-}\right]$, rose abruptly in early 1990 as the North Pacific climate switched to a less energetic state. The selection for diazotrophs during calm conditions is expected, however Karl et al. (1997) suggested that prolonged El Niño conditions would further enhance the role of $\mathrm{N}_{2}$ fixers in bringing new nitrogen into the ecosystem. To the contrary, $\mathrm{N}_{2}$ fixation-supported export abruptly crashed at the end of 1991 despite continuing El Niño conditions. We suspect that the onset of limitation by another nutrient, most likely phosphorus (and/or iron), prevents $\mathrm{N}_{2}$ fixation from staying high indefinitely (Karl et al. 2001). Enhanced eddy-diffusive fluxes of phosphorus from below during energetic La Niña winters could serve to alleviate such a deficiency, which could explain the jump back to high $\mathrm{F}_{\mathrm{PN}}\left[\mathrm{N}_{2}\right]$ observed once the 1996 La Niña had come and gone (Fig. 5). Because diazotrophs can grow with very high $\mathrm{N}: \mathrm{P}$ ratios, a relatively small "refueling" of phosphate into the euphotic zone could allow for a burst of growth and $\mathrm{N}_{2}$ fixation, once summer stratification arrives, that will continue long after the accompanying nitrate is fully utilized. Only extremely energetic conditions will effectively mix diazotrophs downward sufficiently deep to shut down $\mathrm{N}_{2}$ fixation while upwardly mixing sufficient nitrate to "reset" the system to balanced $\mathrm{N}$ : $\mathrm{P}$ conditions (Karl et al. 2001). Iron also could potentially limit $\mathrm{N}_{2}$ fixation in the NPSG; however, it is not clear how La Niña conditions might enhance the primarily springtime eolian inputs of iron to the surface ocean.

We therefore expect to see three types of export "regimes" in the NPSG. Type I: Under highly energetic conditions (perhaps requiring a coincidence of high SOI and high PDOI), $\mathrm{F}_{\mathrm{PN}}\left[\mathrm{NO}_{3}^{-}\right]$will be high and $\mathrm{F}_{\mathrm{PN}}\left[\mathrm{N}_{2}\right]$ low. Type II: Under prolonged, highly stratified El Niño conditions, both $\mathrm{F}_{\mathrm{PN}}\left[\mathrm{NO}_{3}^{-}\right]$and $\mathrm{F}_{\mathrm{PN}}\left[\mathrm{N}_{2}\right]$ will be low. Type III: Under conditions of moderate stratification, $\mathrm{F}_{\mathrm{PN}}\left[\mathrm{NO}_{3}^{-}\right]$will remain low, but sufficient phosphate will be mixed upward during winter/spring to keep $\mathrm{F}_{\mathrm{PN}}\left[\mathrm{N}_{2}\right]$ elevated during the following summer/fall. A Type III condition appears to have persisted since 1996; it is likely that the duration of the 1997-1998 El Niño was insufficient to drive diazotrophs to extreme P limitation (Fig. 5). How long we will have to wait to observe a switch in NPSG climatic conditions back to a Type I regime remains to be seen, although preliminary data suggest that such a transition may have begun in 1998-1999 (Hare and Mantua 2000; Minobe 2000). Nevertheless, our N source deconvolution exercise suggests that climate forcing of export in the NPSG occurs through multiple mechanisms; therefore, the underlying causes of variations in export will not be straightforward to interpret.

\section{References}

Abell, J., S. Emerson, And P. Renaud. 2000. Distributions of TOP, TON and TOC in the North Pacific subtropical gyre: Implications for nutrient supply in the surface ocean and remineralization in the upper thermocline. J. Mar. Res. 58: 203222.

Al-MutaIRI, H., AND M. R. LANDRY. 2001. Active export of carbon and nitrogen at Station ALOHA by diel migrant zooplankton. Deep-Sea Res. II 48: 2083-2103.

Barbeau, K., E. L. Rue, K. W. Bruland, And A. Butler. 2001. Photochemical cycling of iron in the surface ocean mediated by microbial iron(III)-binding ligands. Nature 413: 409-413.

Benitez-Nelson, C., K. O. Buesseler, D. M. Karl, and J. ANDREWS. 2001. A time-series study of particulate matter export in the North Pacific subtropical gyre based on ${ }^{234} \mathrm{Th}:{ }^{238} \mathrm{U}$ disequilibrium. Deep-Sea Res. I 48: 2595-2611.

Capone, D. G., And E. J. CARPenter. 1999. Nitrogen fixation by marine cyanobacteria: Historical and global perspectives. Bull. Inst. Oceanogr. Monaco 19: 235-256.

CARPENTER, E. J. 1983. Nitrogen fixation by marine Oscillatoria (Trichodesmium) in the world's oceans, p. 65-103. In E. J. Carpenter and D. G. Capone [eds.], Nitrogen in the marine environment. Academic.

—, AND K. RomANS. 1991. Major role of the cyanobacterium Trichodesmium in nutrient cycling in the North Atlantic Ocean. Science 254: 1356-1358.

CheCKley, D. M., AND C. A. Miller. 1989. Nitrogen isotope fractionation by oceanic zooplankton. Deep-Sea Res. 36: 14491456.

Church, M. J., H. W. Ducklow, AND D. M. Karl. 2002. Multiyear increases in dissolved organic matter inventories at Station 
ALOHA in the North Pacific subtropical gyre. Limnol. Oceanogr. 47: $1-10$.

Cline, J. D., AND I. R. Kaplan. 1975. Isotopic fractionation of dissolved nitrate during denitrification in the eastern tropical North Pacific Ocean. Mar. Chem. 3: 271-299.

Delwiche, C. C., AND P. L. STEYN. 1970. Nitrogen isotope fractionation in soils and microbial reactions. Environ. Sci. Tech. 4: 929-934.

Deutsch, C., N. Gruber, R. M. Key, J. L. Sarmiento, and A. GanaChaud. 2001. Denitrification and $\mathrm{N}_{2}$ fixation in the $\mathrm{Pa}-$ cific Ocean. Glob. Biogeochem. Cycles 15: 483-506.

Donaghay, P. L., AND OTHERS. 1991. The role of episodic atmospheric nutrient inputs in the chemical and biological dynamics of oceanic ecosystems. Oceanography 4: 62-70.

Dore, J. E., AND D. M. KARL. 1996. Nitrite distributions and dynamics at Station ALOHA. Deep-Sea Res. II 43: 385-402.

Dugdale, R. C., and J. J. Goering. 1967. Uptake of new and regenerated forms of nitrogen in primary productivity. Limnol. Oceanogr. 12: 196-206.

- D. W. MENZEL, AND J. H. Ryther. 1961. Nitrogen fixation in the Sargasso Sea. Deep-Sea Res. 7: 297-300.

Eppley, R. W., AND B. J. Peterson. 1979. Particulate organic matter flux and planktonic new production in the deep ocean. Nature 282: 677-680.

Galloway, J. N., W. H. Schlesinger, H. Levy II, A. Michaels, AND J. L. SCHNOOR. 1995. Nitrogen fixation: Anthropogenic enhancement-environmental response. Glob. Biogeochem. Cycles 9: 235-252.

Glibert, P. M., AND D. A. BRONK. 1994. Release of dissolved organic nitrogen by marine diazotrophic cyanobacteria, Trichodesmium spp. Appl. Environ. Microbiol. 60: 3996-4000.

Hare, S. R., and N. J. Mantua. 2000. Empirical evidence for North Pacific regime shifts in 1977 and 1989. Prog. Oceanogr. 47: 103-145.

Hebel, D. V., AND D. M. Karl. 2001. Seasonal, interannual and decadal variations in particulate matter concentrations and composition in the subtropical North Pacific Ocean. Deep-Sea Res. II 48: 1669-1695.

Hoering, T. C., AND H. T. Ford. 1960. The isotope effect in the fixation of nitrogen by Azotobacter. J. Am. Chem. Soc. 82: 376-378

KARL, D. M. 1999. A sea of change: Biogeochemical variability in the North Pacific subtropical gyre. Ecosystems 2: 181-214.

- AND R. LuKas. 1996. The Hawaii Ocean Time-series (HOT) program: Background, rationale and field implementation. Deep-Sea Res. II 43: 129-156.

- R. Letelier, D. V. Hebel, D. F. Bird, AND C. D. WinN. 1992. Trichodesmium blooms and new nitrogen in the North Pacific gyre, p. 219-237. In E. J. Carpenter, D. G. Capone, and J. G. Rueter [eds.], Marine pelagic cyanobacteria: Trichodesmium and other diazotrophs. Kluwer.

,,--- L. Tupas, J. Dore, J. Christian, And C. WINN. 1995. Ecosystem changes in the North Pacific subtropical gyre attributed to the 1991-92 El Niño. Nature 373: 230234.

, J. R. Christian, J. E. Dore, D. V. Hebel, R. M. Letelier, L. M. TUPAS, AND C. D. WINN. 1996. Seasonal and interannual variability in primary production and particle flux at Station ALOHA. Deep-Sea Res. II 43: 539-568.

$\longrightarrow$, R. Letelier, L. Tupas, J. Dore, J. Christian, And D. HEBEL. 1997. The role of nitrogen fixation in biogeochemical cycling in the subtropical North Pacific Ocean. Nature 388: 533-538.

, AND OTHERS. 2001. Ecological nitrogen-to-phosphorus stoichiometry at station ALOHA. Deep-Sea Res. II 48: 15291566 .
— AND OTHERS. 2002. Dinitrogen fixation in the world's oceans. Biogeochemistry 57: 47-98.

Knauer, G. A., D. G. Redalje, W. G. Harrison, and D. M. Karl. 1990. New production at the VERTEX time-series site. DeepSea Res. 37: 1121-1134.

LETEliER, R. M., AND D. M. KARL. 1996. Role of Trichodesmium spp. in the productivity of the subtropical North Pacific Ocean. Mar. Ecol. Prog. Ser. 133: 263-273.

— AND — 1998. Trichodesmium spp. physiology and nutrient fluxes in the North Pacific subtropical gyre. Aquat. Microb. Ecol. 15: 265-276.

,-- M. R. Abbott, P. Flament, M. Freilich, R. LuKAS, AND T. STRUB. 2000. Role of late winter mesoscale events in the biogeochemical variability of the upper water column of the North Pacific subtropical gyre. J. Geophys. Res. 105: $28,723-28,739$.

LiU, K.-K., AND I. R. Kaplan. 1989. The eastern tropical North Pacific as a source of ${ }^{15} \mathrm{~N}$-enriched nitrate in seawater off southern California. Limnol. Oceanogr. 34: 820-830.

Lukas, R., And F. SAntiago-Mandujano. 2001. Extreme water mass anomaly observed in the Hawaii Ocean Time-series. Geophys. Res. Lett. 28: 2931-2934.

Mague, T. H., F. C. Mague, and O. Holm-Hansen. 1977. Physiology and chemical composition of nitrogen-fixing phytoplankton in the central North Pacific Ocean. Mar. Biol. 41: 213-227.

Mantua, N. J., S. R. Hare, Y. Zhang, J. M. Wallace, and R. C. FRANCIS. 1997. A Pacific interdecadal climate oscillation with impacts on salmon production. Bull. Am. Meteorol. Soc. 78: $1069-1079$.

Martínez, L. A., M. W. Silver, J. M. King, AND A. L. Alldredge. 1983. Nitrogen fixation by floating diatom mats: A source of new nitrogen to oligotrophic ocean waters. Science 221: 152 154.

Marumo, R., AND O. AsaOKA. 1974. Distribution of pelagic bluegreen algae in the North Pacific Ocean. J. Oceanogr. Soc. Jpn. 30: $77-85$

Minagawa, M., And E. Wada. 1984. Stepwise enrichment of ${ }^{15} \mathrm{~N}$ along food chains: Further evidence and the relation between $\delta^{15} \mathrm{~N}$ and animal age. Geochim. Cosmochim. Acta 48: 11351140 .

- AND - 1986. Nitrogen isotope ratios of red tide organisms in the East China Sea: A characterization of biological nitrogen fixation. Mar. Chem. 19: 245-259.

Minobe, S. 1999. Resonance in bidecadal and pentadecadal climate oscillations over the North Pacific: Role in climate regime shifts. Geophys. Res. Lett. 26: 855-858.

. 2000. Spatio-temporal structure of the pentadecadal variability over the North Pacific. Prog. Oceanogr. 47: 381-408.

Montoya, J. P., M. Voss, P. Kähler, And D. G. Capone. 1996. A simple, high-precision, high-sensitivity tracer assay for $\mathrm{N}_{2}$ fixation. Appl. Environ. Microbiol. 62: 986-993.

Moreth, C. M., AND C. S. Yentsch. 1970. A sensitive method for the determination of open ocean phytoplankton phycoerythrin pigments by fluorescence. Limnol. Oceanogr. 15: 313-317.

Orcutt, K. M., F. Lipschultz, K. Gundersen, R. Arimoto, A. F. Michaels, A. H. KNAP, AND J. R. GALlON. 2001. A seasonal study of the significance of $\mathrm{N}_{2}$ fixation by Trichodesmium spp. at the Bermuda Atlantic Time-series Study (BATS) site. DeepSea Res. II 48: 1583-1608.

PAerl, H. W. 1990. Physiological ecology and regulation of $\mathrm{N}_{2}$ fixation in natural waters. Adv. Microb. Ecol. 11: 305-344.

SAINO, T., AND A. HAtTORI. 1987. Geographical variation of the water column distribution of suspended particulate organic nitrogen and its ${ }^{15} \mathrm{~N}$ natural abundance in the Pacific and its marginal seas. Deep-Sea Res. 34: 807-827.

StewART, D. E., AND F. H. FARMER. 1984. Extraction, identification, 
and quantitation of phycobiliprotein pigment from phototrophic plankton. Limnol. Oceanogr. 29: 392-397.

Troup, A. J. 1965. The southern oscillation. Q. J. R. Meteorol. Soc. 91: 490-506.

Villareal, T. A. 1992. Marine nitrogen-fixing diatom-cyanobacteria symbioses, p. 163-175. In E. J. Carpenter, D. G. Capone, and J. G. Rueter [eds.], Marine pelagic cyanobacteria: Trichodesmium and other diazotrophs. Kluwer.

Voss, M., J. W. Dippner, AND J. P. Montoya. 2001. Nitrogen isotope patterns in the oxygen-deficient waters of the eastern tropical North Pacific Ocean. Deep-Sea Res. 48: 1905-1921.

WADA, E., AND A. HATTORI. 1976. Natural abundance of ${ }^{15} \mathrm{~N}$ in particulate organic matter in the North Pacific Ocean. Geochim. Cosmochim. Acta 40: 249-251.

, AND —. 1991. Nitrogen in the sea: Forms, abundances, and rate processes. CRC.

WyMAN, M. 1992. An in vivo method for the estimation of phycoerythrin concentrations in marine cyanobacteria (Synechococcus spp.). Limnol. Oceanogr. 37: 1300-1306.

ZeHR, J. P., AND OTHERS. 2001. Unicellular cyanobacteria fix $\mathrm{N}_{2}$ in the subtropical North Pacific Ocean. Nature 412: 635-638.

Received: 5 February 2002 Amended: 12 June 2002 Accepted: 18 June 2002 